\title{
PRINCIPLES OF RESPONSE TO DETECTIONS OF NEW PLANT PEST SPECIES AND THE EFFECTIVENESS OF SURVEILLANCE
}

\author{
J.A. WILSON, B.P. STEPHENSON, G.S.C. GILL, J.L. RANDALL and \\ C.M.C. VIEGLAIS
}

\author{
MAF Biosecurity Authority, Plants Biosecurity, P. O. Box 2526, Wellington \\ Corresponding author: StephensonB@maf.govt.nz.
}

\begin{abstract}
Surveillance for new plant pests and organisms is an ongoing challenge for the biosecurity of New Zealand. The biggest challenge arises when prioritising which pests to target, as it is not feasible to run active surveillance programmes for the large numbers of pests associated with productive and indigenous ecosystems. Most plant pest detections are through general surveillance, which relies on the public and scientific community to notice and report incursions to the Ministry of Agriculture and Forestry (MAF). MAF recognises the limitations of such an ad hoc process and the resulting implications for responding to incursions of new pests, especially for prospects of containment and eradication. This paper presents three incursion scenarios recognised by MAF and outlines how the level of pest surveillance affects the outcome for incursion management.
\end{abstract}

Keywords: biosecurity, MAF, incursion, eradication, official control.

\section{INTRODUCTION}

The Ministry of Agriculture and Forestry (MAF) plays the leading role in co-ordinating the New Zealand government's biosecurity programme. Included in this programme are proofing New Zealand's borders and managing incursions of new organisms. Incursion management involves technically assessing the likely impacts of the organism, delimiting its distribution, consulting with government agencies, industry and other stakeholders, as well as enforcing Biosecurity Act (1993) and Hazardous Substances and New Organisms Act (HSNO 1996) legislation. In 2001, MAF established an official policy to cover all of these initial activities required when new organisms are detected so as to make appropriate decisions on management (Anon. 2001).

Options available for the management of incursions depend on considerations such as the level of invader establishment and dispersal, the estimated costs and benefits for its management or eradication, and the likelihood of reestablishment. Surveillance is an essential part of such management as it can enable early detection in time for effective containment and eradication action.

MAF's fruit fly trapping programme is the only active surveillance programme currently operated by MAF Plants Biosecurity, and this proved its effectiveness during an outbreak and eradication of Mediterranean fruit fly (Medfly) (Ceratitis capitata) in Auckland in 1996 (Holder et al. 1997). For the most part, incursions of pests on plants are detected by members of the scientific community, industry and the general public, which leads to reports being provided to MAF. Detection of the pests arises through chance, and the chain that includes diagnostic procedure to provide identification and a report or sample submission to MAF is not dependable. With respect to the latter for example, before MAF is involved, significant samples may never be processed and therefore are lost, and reports may become submerged and forgotten. MAF currently refers to the overall process as 'General Surveillance'.

Given the above context, this paper describes different case types of incursions based on surveillance level, detection sensitivity and management options. 


\section{INCURSION MANAGEMENT}

\section{New-to-New Zealand detections}

The pressure on MAF's incursion management capability is growing as new technology allows detection of many organisms that were previously undetectable (e.g. molecular diagnostics and virology). Also, increasing numbers of organisms are being detected and reported as a result of greater awareness, improved surveillance and the inevitable increased rates of influx that are arising from growing trade and tourism. Such trends are reflected in Figure 1, which summarises the number of new organisms affecting plants detected in New Zealand since 1990. All these detections have occurred as a result of General Surveillance, and through this, the organisms had become established and widespread before detection. However, as biosecurity awareness increases the chances of earlier detection of significant pests are likely to increase. With its incursion policy becoming a standard on which to develop procedural systems, MAF is now giving consideration to defining different types of pest incursion to enable greater consistency in decision making. As part of this, MAF Plants Biosecurity has identified classes of incursions which assist with defining the circumstances where intervention to contain and eradicate is appropriate.

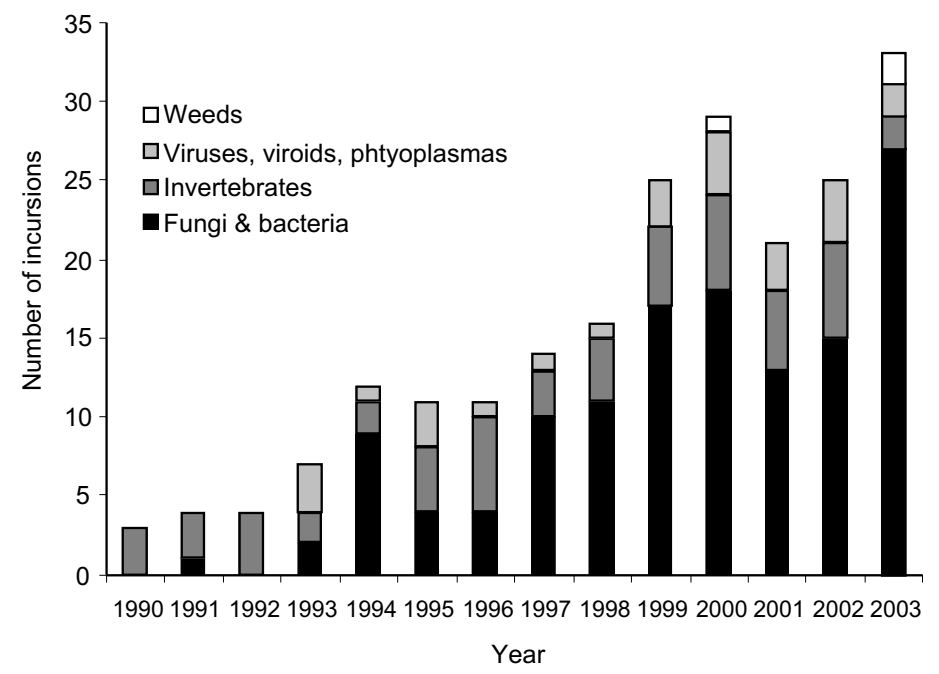

FIGURE 1: Detected incursions of plant-related organisms since 1990, excluding organisms associated with forestry.

\section{Incursion classes}

Three classes of incursion have been defined, which in general terms, equate to the feasibility and implementation of active surveillance. Case 1 applies to incursions where detection occurs in time for prompt eradication, typically where investment in active surveillance has occurred. Case 2 applies to incursions where pest dispersal has already occurred, but distribution is still sufficiently restricted for the cost:benefit analysis of eradication to be favourable. Lastly, Case 3 applies to pests that are widely dispersed at the time of detection, and which have established well beyond a level where cost effective action is feasible. 
Table 1 lists significant incursions of plant-related organisms since 1996 and categorises them as either case 1, 2 or 3 based on the above descriptions. The table shows that case 3 incursions are by far the most numerous.

TABLE 1: Significant incursions of plant-related organisms excluding organisms associated with forestry.

\begin{tabular}{|c|c|c|c|}
\hline New organism & Host & Identification date & Case \\
\hline Depressaria pastinacella & Heracleum sphondylium & 2 Feb 2004 & 3 \\
\hline Cecidophyopsis hendersoni \& & Yucca elephantipes & & \\
\hline Oziella yuccae (Yucca mites) & (Yucca) & Jan-Feb 2004 & 3 \\
\hline $\begin{array}{l}\text { Naohidemyces vaccinii } \\
\text { (Blueberry rust) }\end{array}$ & $\begin{array}{l}\text { Vaccinium ashei } \\
\text { (Blueberry) }\end{array}$ & 9 Jan 2004 & 3 \\
\hline Soil-borne wheat mosaic virus & Triticum aestivum & $9 \mathrm{Jan} 2004$ & 3 \\
\hline (SBWMV) & (Wheat) & 11 Dec 2003 & 3 \\
\hline $\begin{array}{l}\text { Impatiens necrotic spot virus } \\
\text { (INSV) }\end{array}$ & $\begin{array}{l}\text { Freesia refracta } \\
\text { (Freesia) }\end{array}$ & 22 Aug 2003 & 3 \\
\hline $\begin{array}{l}\text { Cycas necrotic stunt virus } \\
\text { (CNSV) }\end{array}$ & $\begin{array}{l}\text { Paeonia lactiflora } \\
\text { (Paeony) }\end{array}$ & 31 Jul 2003 & 3 \\
\hline $\begin{array}{l}\text { Nasonovia ribis-nigri } \\
\text { (Lettuce aphid) }\end{array}$ & $\begin{array}{l}\text { Lactuca sativa } \\
\text { (Lettuce) }\end{array}$ & 3 Apr 2002 & 3 \\
\hline Frankliniella intonsa & Fragaria $x$ ananassa & 3 Apr 2002 & 3 \\
\hline (Eastern flower thrips) & (Alpine strawberry) & 19 Feb 2002 & 3 \\
\hline $\begin{array}{l}\text { Potato spindle tuber viroid } \\
\text { (PSTvd) }\end{array}$ & $\begin{array}{l}\text { Lycopersicon esculentum } \\
\text { (Tomato) }\end{array}$ & 11 Jan 2001 & 2 \\
\hline $\begin{array}{l}\text { Coscinoptycha improbana } \\
\text { (Australian guava moth) }\end{array}$ & $\begin{array}{l}\text { Citrus reticulate } \\
\text { (Mandarin) }\end{array}$ & 24 Aug 1999 & $2-3$ \\
\hline $\begin{array}{l}\text { Pseudomonas savastanoi pv. } \\
\text { Savastanoi (Olive knot) }\end{array}$ & Orea europaea & $-1.200 \%$ & 2 \\
\hline $\begin{array}{l}\text { Savastanol (Uive Knot) } \\
\text { Sitona lepidus }\end{array}$ & $\begin{array}{l}\text { (Olive) } \\
\text { Tifolium repens }\end{array}$ & & 2 \\
\hline (Clover root weevil) & (White clover) & 13 Mar 1996 & 3 \\
\hline $\begin{array}{l}\text { Ceratitis capitata (Mediterranean } \\
\text { fruit fly) - Eradicated }\end{array}$ & Wide host range & May 1996 & 1 \\
\hline
\end{tabular}

\section{Case 1}

The early detection of pests by active surveillance in Case 1 incursions results in benefits of eradication far exceeding the cost, although the overall cost-benefit analysis must also include the cost of on-going surveillance. To this effect, MAF assumes that part of the preparation/analysis for a contingency involving this investment would also include the application of specific border controls to minimise the possibility of reintroduction. In the absence of specifically designed pest management strategies under the Biosecurity Act 1993 (the Act), MAF intervention would almost certainly involve application of Part VI powers of the Act, which provides powers to carry out essential actions, such as inspection, sampling, applying treatments, and restricting movements of things which might spread pests. The Mediterranean fruit fly (Ceratitis capitata) incursion response in Auckland in 1996 typifies a Case 1 incursion, as a specific trapping programme was in place that led to its early detection. Although the resulting programme continued for a year after the detection (Holder et al. 1997), the prompt follow-up action enabled the population to be rapidly controlled. All of the 41 trapped adults and 86 larvae detected in fruit were found within the first three weeks of the programme, and no further detections occurred thereafter.

MAF has investigated the potential for active surveillance for pests other than fruit fly (Stephenson et al. 2003; Ganev \& Braithwaite 2003), and unless other parties besides 
central government become involved, the scope of further initiatives maybe limited. Industry is becoming increasingly aware of this and is now discussing approaches to preventing establishment of pests of concern. For example, The New Zealand Vegetable \& Potato Growers' Federation (Inc) (Vegfed) together with MAF are investigating ways to improve the present arrangements for potato wart (Synchitrium endobioticum) containment and eradication. This disease occurs sporadically in home garden potatoes in Invercargill, and MAF's Official Control programme includes fumigation when discovered.

\section{Case 2}

These incursions may be detected through General Surveillance, or possibly through a specific surveillance programme. Although pest dispersal has already occurred, distribution is still sufficiently restricted for the cost:benefit analysis of eradication to be favourable. Typically, such a General Surveillance detection might involve a very distinctive and striking pest which is easily seen. Detection may also occur through a directed programme when the pest may be covert but its potential impact justifies surveillance expenditure.

Given the amount of dispersal, attempts to eradicate such an incursion would be accompanied by a clearly identifiable risk of eradication failure. During this process, comprehensive and sometimes difficult discussions with the affected parties can be expected while formulating an appropriate programme. The greatest difficulties and management challenges are associated with these events.

\section{Case 3}

Case 3 incursions are most frequently encountered and they involve pests for which no specific surveillance arrangements have been in place. These pests are widely dispersed at the time of detection, and have established well beyond a level where cost effective action is feasible. At detection, MAF may apply containment actions while further survey work is undertaken to determine distribution and while consulting with affected parties on management options.

In this case, the cost of eradication would exceed the benefits, and appropriate action is therefore to seek agreement from affected parties on the basis that eradication is not feasible. However, action to slow pest spread may be feasible, but other than this, the most attractive option would be to operate an extension programme to raise awareness of the threat and currently available controls, and to initiate/organise research into the pest's biology and management.

A recent example of a Case 3 incursion is the detection of two species of Yucca mites (Cecidophyopsis hendersoni and Oziella yuccae) on yuccas (Yucca elephantipes) associated with the nursery trade in January and February 2004 respectively. Cecidophyopsis hendersoni and $O$. yuccae are tiny 4-legged worm-like eriophyoid mites, which are usually invisible to the naked eye (approx. $0.2 \mathrm{~mm}$ ). These two species are only known from Yucca species (Armine \& Stasny 1994), and the literature indicates that they are not a significant pest of Yucca production and can be controlled by the use of miticides (Labanowski 1999). MAF conducted a survey on receipt of the confirmed identification and established that $C$. hendersoni was present in Wellington, Napier and Auckland. The indications were that further action was not warranted owing to its wide distribution in the nursery trade, although there may be further discussion owing to new organism status under the HSNO Act (1996), and the remote possibility of alternative hosts being present in indigenous flora. While these concerns are being resolved, the company owning the plants has been advised of their legal obligations in that it is not to disperse the pests as per the Biosecurity and HSNO Acts.

\section{CONCLUSIONS}

The majority of incursions of plant-related organisms managed by MAF Plant's Biosecurity are Case 3 incursions in which organisms are detected by chance, are widely dispersed and eradication is likely to fail and/or be extremely costly relative to the benefits. 
MAF sees greatest potential for incremental improvements to be made to current arrangements through surveillance contribution by other affected parties. This will be the most likely way that more Case 1 detections occur in the future.

\section{ACKNOWLEDGEMENTS}

We thank the NPPRL incursion investigators and science staff who assisted with identifying and investigating the above examples of plant organism incursions. We also thank the potato product sector of the New Zealand Vegetable \& Potato Growers' Federation (Inc).

\section{REFERENCES}

Anon. 2001: MAF Biosecurity Authority Policy statement on responding to an exotic organism incursion. Ministry of Agriculture and Forestry, Wellington, New Zealand.

Armine, J.W.; Stasny, T.A. 1994: Catalog of the Eriophyoidea (Acarina: Prostigmata) of the world. Indira Publishing House, Michigan, USA. 798 p.

Ganev, S.; Braithwaite, M. 2003: Resource requirements for national active surveillance programmes of high impact exotic pests in New Zealand. N. Z. Plant Prot. 56: 10-15.

Holder, P.W.; Stephenson, B.; Chadfield, K.; Frampton, R. 1997: The finding of Mediterranean fruit fly in Auckland, New Zealand and the Ministry of Agriculture's response. Weta 20(1): 4-6.

Labanowski, G. 1999: Occurrence and chemical control of introduced ornamental glass house pests in Poland. Bulletin OEPP/EPPO 29: 73-76.

Stephenson, B.P.; Gill, G.S.C.; Randall, J.L.; Wilson, J.A. 2003: Biosecurity approaches to surveillance and response for new plant pest species. N. Z. Plant Prot. 56: 5-9. 